\title{
Metateoretiese vertrekpunte ten opsigte van wetenskaplike navorsing in die Liturgiek
}

\author{
Author: \\ Barend J. de Klerk ${ }^{1}$ \\ Affiliation: \\ ${ }^{1}$ School for Ecclesiastical \\ Sciences, North-West \\ University, Potchefstroom \\ Campus, South Africa \\ Correspondence to: \\ Ben de Klerk \\ Email: \\ ben.deklerk@nwu.ac.za \\ Postal address: \\ PO Box 20764, Noordbrug \\ 2522, South Africa \\ Dates: \\ Received: 28 July 2011 \\ Accepted: 14 Feb. 2012 \\ Published: 10 Apr. 2013 \\ How to cite this article: \\ De Klerk, B.J., 2013, \\ 'Metateoretiese \\ vertrekpunte ten opsigte van \\ wetenskaplike navorsing in \\ die Liturgiek', In die Skriflig/ \\ In Luce Verbi 47(1), Art. \\ \#89, 9 pages. http://dx.doi. \\ org/10.4102/ids.v47i1.89 \\ Copyright: \\ (C) 2013. The Authors. \\ Licensee: AOSIS \\ OpenJournals. This work \\ is licensed under the \\ Creative Commons \\ Attribution License.
}

Read online:
Om die nuwe ontwikkelings in die Liturgiek grondig te kan beoordeel, moet na die metateoretiese onderbou van die verskillende standpunte gekyk word. Wanneer 'n navorser op die terrein van die Liturgiek nie hierdie wendings in sy metateoretiese vertrekpunte verreken nie, kan sodanige navorser of meegesleur word deur hierdie denkrigtings, of aan die ander kant, impulsief reaksionêr 'n onwetenskaplike oordeel daaroor uitspreek. Die navorsingsartikel het daarom ten doel om die eie reformatoriese metateoretiese vertrekpunte ten opsigte van die Liturgiek te probeer formuleer en om vas te stel wat die invloed daarvan is in die konteks van wendings in die denkklimaat asook die leefwêreld en kultuur waarin die wetenskaplike taak uitgevoer word. Hierdie navorsingsartikel het verder ten doel om 'n voorbeeld daar te stel hoe hierdie metateoretiese beskouing 'n navorsingsprojek kan stuur. Die wyse waarop God in die doop werksaam is en die effek daarvan op vergifnis en versoening in die Suid-Afrikaanse konteks, is die voorbeeld van hoe 'n navorsingsprojek in die wetenskap van die Liturgiek aangepak kan word.

Metatheoretical points of departure with regard to scientific research in Liturgy. To be able to thoroughly judge the new developments in liturgy, the metatheoretical underpinnings of the different viewpoints must be examined. When a researcher in the field of Liturgy does not take these alterations on his metatheoretical points of departure into consideration, one can be carried away by these schools of thought, or on the other hand, express an unscientific judgement in an impulsive reactionary manner. The objective of this research article is therefore to try and formulate reformed metatheoretical points of departure with regard to Liturgy and to determine the impact thereof in the context of alterations in the climate of thought, the world we are living in and the culture within which the scientific task is carried out. A further objective of the research article is to provide an example of the way in which this metatheoretical view can steer a research project. The way in which God is working through baptism and the effect thereof on forgiveness and reconciliation in the South African context, is an example of the way in which a research project can be undertaken in the science of Liturgy.

\section{Inleiding}

Hierdie artikel is deel van 'n reeks oor die verrekening van die metateoretiese vertrekpunte in die wetenskap van die Praktiese Teologie. Die eerste fase van die reeks bied die teoretiese onderbou vir die werklikheids-, hermeneuties- en wetenskapsteoretiese beskouing van die vak. Die tweede fase fokus op die invloed wat hierdie vertrekpunte op die wetenskaplike navorsing van die verskillende vakgroepe in die Praktiese Teologie het. Hierdie artikel handel oor die wetenskaplike benaderingswyse tot die navorsingsveld van die Liturgiek.

In die Liturgiek word nie slegs die lewe van die kerk weerspieël nie, maar hier trek die lyne van die Teologie ook saam (De Klerk 1987:iii). Liturgie het daarom 'n sterk teologiese onderbou en is ook ' $n$ praktiese refleksie van die lewe van die kerke wat liturgie beoefen. Ten diepste sou die ideaal van alle kommunikatiewe handelings in die liturgie van die samekoms (erediens) en die liturgie van die lewe uitgedruk kon word in die woorde van die buitestander in 1 Korintiërs 14:25: 'Waarlik God is hier by julle!' Dit gaan dus om die raaksien, ervaring en belydenis van God se teenwoordigheid en die kommunikatiewe handeling tussen God en 'julle', die samekoms van die gemeente. Hoewel Liturgiek meer omvat as net die handelings binne die samekoms van die gemeente, is die fokus in hierdie artikel op laasgenoemde.

As gevolg van die wendings in die kontekste waarin die liturgie afspeel, byvoorbeeld die gees van materialisme en postmoderne tendense, het daar die afgelope vyf dekades nuwe fokuspunte in die liturgiese handelings gekom (Dawn 1995:24). 'n Kort oorsig oor die ontwikkelings in die 
Liturgiek en kerklike praktyk van die afgelope eeu toon watter dinamiese wendings gedurende die afgelope vyf dekades plaasgevind het.

Kuyper het in 1897 (Kuyper 1911) in De Heraut 'n reeks artikels geskryf wat uiteindelik beslag gekry het in sy omvattende boek oor die Liturgiek, Onze eredienst. Hy dui daarin aan dat die liturg nie oor die gemeente beskik en dus willekeurig kan handel nie. Die vorm van die erediens is nie willekeurig nie en daar moet ' $n$ vaste orde kom aan die hand van beginsels uit die Skrif en afgelei uit die reformatoriese tradisie (Kuyper 1911:237-241). Sy standpunte vorm die basis vir die stabiliteit van die Liturgiek vir meer 70 jaar onder andere in gereformeerde kerke in Nederland en Suid Afrika, waarin byna alleen oor die moontlike verskuiwings van liturgiese elemente binne die erediens gedebatteer is. Die Liturgiese Beweging van die twintigste eeu sluit hierby aan om in die sewentigerjare van die vorige eeu vernuwende elemente soos nuwe liedere en nuwe formuliergebede, nuwe vorms te beproef en ouer vorms te herontdek (Barnard 2006:23). Onder invloed van die Modernisme is daar logiese verklarings en dit bring stabiliteit in die kerklike praksis op liturgiese gebied, byna tot in die negentigerjare van die twintigste eeu. Die Liturgiek was op wetenskaplikes, akademiese werk en liturgiese opleiding van toekomstige predikante toegespits (Dijk 1999:399).

Die Liturgiek kon nie die kerklike invloed van die Charismatiese beweging en die sosiale kontekste van die Sekularisme en postmoderne tendense vryspring nie (Compaan 2007:348). Dit het, in die woorde van Barnard (2006), die liturgie verby die Liturgiese Beweging laat ontwikkel. Gemeentes het in die vroeë negentigerjare, as gevolg van 'n obsessie om in 'n nuwe konteks te oorleef, al meer op hulleself begin konsentreer. Daardeur word die liturgiek meer en meer deur die dinamiek van kultus en kultuur bepaal (Tovey 2004:3). Aan die begin van die eenen-twintigste eeu word die normatiewe en vaste vorms van die liturgie verruil vir 'n liturgia condenda, 'n liturgie wat in 'n spesifieke konteks ontwikkel word. Barnard stel dit duidelik vanuit die Europese en spesifiek Nederlandse konteks: 'De context is een beslissende faktor geworden, de liturgie ontstaat in de dynamiek van de context en de participanten' (Barnard 2006:30). Vanuit 'n Suid-Afrikaanse konteks onderskei Burger (2003:165) veral twee lyne: 'n meer evangelical praize and worship en 'n verryking of verdieping van die tradisionele liturgie.

'n Verdere wending, wat nog nie so sterk in die SuidAfrikaanse konteks gegroei het nie, is die sogenaamde buitekerklike individualistiese spiritualiteit van simbole en rituele. In hierdie beweging is dit moontlik om op die Internet 'n eie altaar te ontwikkel as 'n soort spirituele hawe (vgl. Barnard 2006:133-138).

Die gevolg van hierdie postmoderne invloede in die liturgiek is dat ' $n$ verbruikerskultuur van die samelewing in sommige kerklike bewegings posgevat het en dat die smake en voorkeure van die 'verbruiker' van die liturgie eerder dié van 'n toeskouer as 'n deelnemer aan liturgiese handelings geword het (Lathrop 1996:73). Hierdie tendens het gelei tot eksperimentering en nabootsing van aanbiddingsgeleenthede waar dit 'werk' (Smit 2003:491).

Breedweg kan enkele van die wendings ook getipeer word as verskuiwings (nie noodwendig altyd slegte verskuiwings nie). Die volgende is hier ter sprake:

- Verskuiwings van God wat primêr in die samekoms die Handelende is en wat die gemeente as deelnemers in antwoord op sy handelings na menslike spirituele ervarings laat reageer;

- Verskuiwings van vaste vorms, afgelei uit bronne wat vir die kerke gesaghebbend was, na soms onvoorspelbare handelings waar die liturg en die gehoor op die ingewing van die oomblik (soms aangedui as 'gelei deur die Gees') handel;

- Verskuiwings van die fokus op die gehoor na 'n hoofsaaklik visuele instelling in die liturgiese handelings (De Wet 2007:605);

- Verskuiwings van algemeen geldende liturgiese handelings in alle kerke binne dieselfde kerkverband na konteksbepalende liturgiese handelings.

Om hierdie tendense grondig te kan beoordeel, moet na die metateoretiese onderbou van die verskillende standpunte gekyk word. Wanneer 'n navorser op die terrein van die Liturgiek nie hierdie wendings in die metateoretiese vertrekpunte verreken nie, kan 'n mens óf meegesleur word deur hierdie denkrigtings, óf impulsief reaksionêr 'n onwetenskaplike oordeel daaroor uitspreek. Aan die een kant kan die vaste vorms onregmatig aan Skrifbeginsels toegeskryf word, of tradisionalisties verdedig word. Aan die ander kant kan daar so 'n oorbeklemtoning van die eie konteks en die deelnemers gemaak word, dat die samekoms 'n samekoms word van vreugdevolle spirituele deelnemers, sonder dat hulle bewus is dat die samekoms in sy wese 'n ontmoeting van God met sy volk is (vgl. Kubicki 2006:35).

Hierdie navorsingsartikel het daarom ten doel om die eie reformatoriese metateoretiese vertrekpunte ten opsigte van die Liturgiek te formuleer. Verder is die doel om vas te stel wat die invloed daarvan is in die konteks van wendings in die denkklimaat, leefwêreld en kultuur waarin die wetenskaplike taak uitgevoer word.

Die navorsingsartikel het verder ten doel om 'n voorbeeld daar te stel hoe hierdie metateoretiese beskouing 'n navorsingsprojek stuur. Die wyse waarop God in die doop werksaam is en die effek daarvan op vergifnis en versoening in die Suid-Afrikaanse konteks, is 'n voorbeeld van hoe 'n navorsingsprojek in die wetenskap van die Liturgiek aangepak kan word.

Vir hierdie doeleindes word gebruik gemaak van Osmer (2008:58) se definisie van elemente waaruit ' $n$ metateoretiese perspektief saamgestel is: 'A metatheoretical perspective, thus is composed of the assumptions about reality, knowledge and 
science that transcends particular research projects and theories.' In die loop van hierdie navorsingsartikel word die eie metateoretiese perspektief waarmee die vakgebied van die Liturgiek benader word, uitgespel en verantwoord ten opsigte van die volgende aspekte:

- Die werklikheidsbeskouing waarmee daar op die navorsingsveld van die Liturgiek gefokus word.

- Die onderbou rakende die hermeneutiese beskouing wat nodig is om tot ' $n$ verstaan en verantwoordelike inrigting te kom van die verhouding tussen die kommunikatiewe elemente wat in die liturgiese proses ter sprake kom.

- Die wetenskapsteoretiese benadering waarmee die navorsingsveld van die Liturgiek op 'n wetenskaplik verantwoorde wyse ondersoek kan word (De Wet \& Pieterse 2010:537-538).

\section{Verrekening van metateoretiese aspekte rakende 'n werklikheidsbeskoulike benadering tot die Liturgiek}

In die prakties-teologiese wetenskapsbeoefening fokus die Liturgiek ook op die gebeurlikheidsdimensie in die waarneembare werklikheid van menslike handelings wat deur die goddelike werking van die Woord en Gees bepaal word (De Wet 2006:81). Die kommunikatiewe handelings in die erediens is sentrale handelings wat in die Praktiese Teologie bestudeer word. God neem in hierdie handelings die inisiatief deur die gemeente in Christus deur die Gees te ontmoet en met hulle in kommunikasie (geloofsgemeenskap) te tree. Die gemeente is die kommunikasiegemeenskap wat met God en met mekaar, asook met die samelewing waarin die gemeente in voortdurende dialoog leef, in 'n lewende verhouding en innige gemeenskap verkeer (Vos \& Pieterse 1997:16).

Die kommunikatiewe gebeure in die ondersoekveld van die Liturgiek vind in 'n bepaalde ruimte plaas waarin God, die liturg en die gemeente met mekaar in 'n verhouding gebring word. Die ontmoeting in hierdie ruimte word verder ook deur die unieke konteks bepaal om dit kultureel en kulties te stempel. Die liturgiese kommunikatiewe gebeure het 'n temporele aspek, want die liturg en die erediensdeelnemers het ' $n$ verlede, hede en toekoms wat in die werklikheidsbeskouing in aanmerking geneem moet word (vgl. Heitink 1993:153). Dit raak ook die kontemporêre aspek van die erediensdeelnemers se verbinding aan geslagte in die bybelse tyd en in die loop van die kerkgeskiedenis, waardeur bepaalde tradisies gevestig geraak het. Kontinuïteit en diskontinuïteit kom in liturgiese besluite in die spel.

In die werklikheidsbeskouing word die deurslaggewende rol gespeel deur die wyse waarop die liturg en die erediensdeelnemers in die kommunikasieprosesse by God se handelings betrokke raak. In hierdie opsig moet die werklikheidsbeskouing die plek van God, die gesag van die Woord en die verhouding tussen God as Subjek en die liturg en die erediensdeelnemers as subjekte in aanmerking neem.
Wendings die afgelope twee dekades vanaf formele liturgiese ordes na meer informele handelings, dikwels op die ingewing van die oomblik, is ook toe te skryf aan die beskouing van God se handelings in die liturgiese gebeure. Die betrokkenheid van God in die gebeurlikheidsdimensie van die samekoms van die gemeente is hierdeur hoofsaaklik tot die blote werking van die Heilige Gees beperk. Dit het tot ' $n$ oordrewe charismatiese instelling gelei waarin sowel die liturg as die gemeente willekeurig, sonder metateoretiese verantwoording, impulsiewe besluite oor liturgiese gebeure kan neem (Wepener 2007:734). Die postmoderne invloed het ook meegebring dat liturgiese handelings hoofsaaklik deur die erediensdeelnemers verrig word en daar is die gevaar dat God tot ' $n$ ontvanger gedegradeer kan word wanneer hierdie benadering gevolg word. Sodanige antroposentriese tendens in die liturgiese handelings verg 'n antwoord vanuit metateoretiese vertrekpunte oor wie God is en wat sy handeling in die erediensgebeure is.

Vanuit die reformatoriese gesigspunt word die samekoms van die gemeente as 'n drieërlei ontmoeting getipeer. Eerstens is dit 'n ontmoeting wat God inisieer en sy inisiatief maak dit vir die erediensdeelnemers moontlik om God en mekaar in dialogiese kommunikatiewe handelings te ontmoet. God ontmoet die gemeente in die Middelaar, Jesus Christus, wat op grond van sy kruis en opstanding versoening gebring het en dus gemeenskap moontlik maak. Christus staan dus sentraal in die kommunikasiegebeure van die erediens (Kubicki 2006:54). Hy maak die dialogiese ontmoeting moontlik deur die werking van sy Gees in die erediensdeelnemer en bewerk die ontmoeting deur die Woord, wat proklameer, vermaan en vertroos en wat van die erediensdeelnemers 'n antwoord vra. Die reformatoriese vertrekpunt is op 'n teosentriese standpunt gegrond waarin God op trinitariese wyse by die gebeurlikheidsdimensie in die werklikheid betrokke is (De Wet \& Pieterse 2010:532). Die teenwoordigheid van God behoort as beoordelingsraamwerk gebruik te word om navorsers te oriënteer ten opsigte van die ontstaan, ontwikkeling of verwikkeling en einde of voleindiging of bestemming van alles wat in die spanningsveld van die liturgiese navorsingsterrein waargeneem word.

Vanuit die reformatoriese metateoretiese vertrekpunte is die Skrif die gesagsbron, die primêre kenbron vir die interpretasie van die liturgiese handelings wat waargeneem word. In die Woord openbaar God genoegsaam op watter wyse Hy in die liturgiese kommunikasiegebeure betrokke is en hoe die liturg en die erediensdeelnemers dialogies daarop kan reageer. Die Skrif bevat beginsels wat koers in die liturgiese beoordeling kan aandui en ook gesonde, vernuwende, verdiepende en dinamiese ontwikkeling in die Liturgiek kan meebring (De Klerk 2007:3). In die navorsingsveld van die Liturgiek kan aanvaar word dat die Skrif genoegsame lig werp om tot die verstaan van die essensiële elemente te kom wat daarin teenwoordig mag wees, gesindhede wat daarin ter sprake kom om dit bloot te lê en duidelike merkers vir vernuwing van die praksis aan te dui. 
Die reformatoriese metateoretiese beskouing van die werklikheid waarin die liturgiese handelings afspeel, raak ook die verhouding tussen die goddelike Subjek en die menslike subjek. Die menslike handelings in die liturgiese aktiwiteit is altyd in die goddelike handelings geanker, want God roep juis in die erediens antwoord en aksie van die erediensdeelnemer op. God rig Hom bewustelik kommunikatief op die liturg en die erediensdeelnemers; en die liturg en die erediensdeelnemers as subjekte rig hulle in die geloof op God en mekaar in hulle liturgiese handelings. Daar is resiprositeit (wederkerigheid) en asimmetrie in die Goddelike en menslike verhoudings in hierdie handelings (De Wet \& Pieterse 2010:532). Die menslike handelings sal dus ook ondersoek word in die mate waarin dit van geloofsgerigtheid op God spreek. Die kommunikatiewe proses vind binne die verbondsruimte plaas waarin God Hom aan die erediensdeelnemers verbind wat Hy begenadig en Hy verwag dat hulle Hom volledig sal liefhê.

Wanneer die navorser sekere metateoretiese vertrekpunte ten opsigte van die werklikheidsbeskouing eerlik uitspel en dit teenoor beskouings stel wat ander vertrekpunte beklemtoon, kan die genoemde reformatoriese vertrekpunte steeds geëvalueer en gereformeer word (vgl. Van der Walt 2010:81). Op hierdie wyse kan veral leemtes, eensydighede en reaktiewe optrede uitgeskakel word. Daar kan veral aandag gegee word aan moontlike beskuldigings dat hierdie beskouing nie genoegsame ruimte maak vir die werking van die Gees, die aktiewe deelname van die erediensdeelnemers en die spontaneïteit in die samekoms nie (vgl. Dreyer 2005:105).

\section{Verrekening van metateoretiese aspekte rakende ' $n$ hermeneutiese benadering tot die Liturgiek}

Die werklikheid van die liturgies-kommunikatiewe handelings wat verstaan, verklaar en verander behoort te word, is 'n bewegende en dinamiese werklikheid (Pieterse 2011:729). In die kommunikatiewe gebeure is daar dus 'n hermeneutiese proses wat ook die uitspel van metateoretiese vertrekpunte vereis en 'n vergelyking hiervan met vertrekpunte wat moontlik van die reformatoriese vertrekpunte verskil. Sonder verantwoordbare hermeneutiese beginsels kan wanpersepsies ontstaan wat tot voorstelle vir verandering kan lei wat deformerend op die erediens inwerk en die erediens laat ontaard in 'n eensydige antropologiese gebeurtenis, óf 'n eenmansvertoning deur die liturg. Wendings op die liturgiese toneel in die hermeneutiese benadering kan veral verstaan word wanneer daar enersyds sterker klem op die wisselwerking tussen Skrifbeginsels en teologiese tradisies geplaas word en die konteks van die erediensdeelnemer andersyds. In die grootste deel van die vorige eeu het die verstaanproses hoofsaaklik uit die studie van Skrifbeginsels en historiese tradisies bestaan (Barnard 2006:25). Die resultaat van die verstaanproses het die erediensdeelnemer se kultuur en konteks nie voldoende in berekening gebring nie. Die pneumatologiese perspektief, die wisselwerking in die verstaan, spanningsvelde in die verstaan en die verloop van die hermeneutiese proses, moet ook aan die orde kom.

Die pneumatologiese perspektief vorm die invalshoek vir die reformatoriese vertrekpunte in die hermeneutiese benadering tot liturgiese handelings. Die Gees is in Christus veranker en die Skrif kan nie verstaan word sonder die hermeneutiese sleutel van Jesus Christus nie. Calvyn onderstreep die feit dat ons God, onsself en mekaar eers werklik kan leer ken wanneer ons die Skrif lees onder die verligting van die Heilige Gees (Calvijn 1956:37-42). Dieselfde Heilige Gees is in die liturgiese gebeure in die erediensdeelnemer werksaam en daarom behoort die erediensdeelnemer se konteks (d.w.s. sy persoon, omstandighede, kultuur, leefwêreld en tyd) ook in die hermeneutiese proses betrek te word. Die werksaamheid van die Heilige Gees vereis verder dat sowel die liturg as die erediensdeelnemer biddend in die liturgiese gebeure betrokke is. Vanuit die reformatoriese hoek gesien, behoort die noodsaak van gebed as metateoretiese vertrekpunt duidelik uitgespel te word.

Daar sal dus 'n dialogiese wisselwerking in die liturgiese handelings plaasvind wat' $n$ interpretatiewe interaksie behels tussen die Skrif en die tradisie aan die een kant en die konteks en die werklikheid van die liturgiese handelings aan die ander kant (vgl. Vos \& Pieterse 1997:18). Die wisselwerking is tussen die eie teologiese tradisie, met die Skrif as kriterium, 'n teosentriese verstaan van God in Christus en die verstaan van die erediensdeelnemer as begenadigde sondaar, vernuwe om op God se Woord te kan antwoord. Die werking van God bring ' $n$ verruiming in die horisonne van die verstaan van die liturgiese handelings. Die vorm van die kommunikasie in 'n dialogiese teorie is altyd onafgeslote, 'open-ended' (Pieterse 1995:68). Die hermeneutiese proses word nooit voltooi nie, want betekenis is nie ' $n$ vaste objek nie, maar 'n dialogiese proses waarin dit in elke nuwe historiese konteks van die betrokke lesers opnuut deurbreek. Elke historiese konteks vorm sy eie verstaanhorison. Dialoog is 'n voortgaande proses wat nie in sirkels draai nie, maar soos 'n spiraal na bo beweeg op die weg van dieper insig, meer groei, onderlinge begrip en meer betrokkenheid by mekaar (Vos \& Pieterse 1997:26). Dit beteken dat die horison wat vanuit die teologiese tradisie afkomstig is en die horison(ne) wat vanuit die konteks van die erediensdeelnemer verkry word, in hierdie proses al hoe meer oor mekaar skuif om daardeur verstaan moontlik te maak.

'n Navorsingsprojek in die Liturgiek vind plaas in die bipolêre spanningsveld van die geopenbaarde Woord van God (en ons verstaan daarvan in teorieë geformuleer) en die konkrete werklikheid van die liturg en die erediensdeelnemer binne die konteks van die samelewing waarin die erediens geskied. Hierdie spanningsveld kom tot stand wanneer vraagstukke in verband met die behoud van die status quo of vernuwing van die liturgiese handelings ter sprake kom. Die spanning en interaksie tussen teorie en praktyk lei tot die formulering daarvan in nuwe teorieë. Hierdie teorieë word 
uit die hermeneuties-wetenskaplike interaksie tussen teorie en praktyk gebore (Pieterse 2011:723).

Reformatoriese vertrekpunte in die verloop van die verstaanproses behels onder andere die doelbewuste uitspel van die navorser se vooroordele, voorverstaan en geloofsverstaan van liturgiese handelings, asook om die interpretasiegeskiedenis van die Liturgie in berekening te bring, veral ten opsigte van die resente verlede. Die hermeneutiese wisselwerking en/of kritiese konfrontasie tussen die Skrif en die erediensdeelnemer is asimmetries. Die Skrif het die primaat en breek nuwe insigte en grond in die liturgiese handelings oop. In die verloop van hierdie verstaanproses behoort die volgende in interaksie met mekaar gebring te word: God se handeling soos dit in die Skrif (as primaat) geopenbaar word, die teologiese tradisie, empiriese resultate wat veral uit kwalitatiewe navorsingverkry word, asook insigte van aangrensende wetenskappe wat bydra tot die verstaan van die konteks, kultuur en tyd waarin die liturgiese gebeure plaasvind (Pieterse 2002:92).

\section{Verrekening van metateoretiese aspekte rakende' $n$ wetenskapsteoretiese benadering tot die Liturgiek}

In hierdie afdeling gaan dit oor die vraag hoe daar op wetenskaplike vlak teorieë ontwerp kan word om die praksis te begryp, lewensontsluitende norme daarop te rig en dit met verantwoordelikheid in 'n rigting te stuur (De Klerk, De Wet $\&$ Pieterse 2012). Liturgiek behoort in die lig hiervan aan 'n redelik algemene definisie van wetenskap getoets te word: 'Wetenskap is 'n sisteem van konsepte, teorieë, bevindinge en metodes wat deur 'n aantal wetenskaplikes aanvaar word.' (Mouton \& Marais 1989:160.) Die volgende werksdefinisie vir liturgiese wetenskapsbeoefening word gebruik:

Liturgiek is die wetenskaplike studie van die kommunikatiewe handelinge tussen God as dié Liturg, die liturg van die gemeente en die erediensdeelnemers. Die invalshoek waarmee die Reformatoriese navorser in Liturgiek sy/haar studieveld benader, word bepaal deurdat eie vooroordele onder leiding van die Gees van Christus geplaas word sodat met onderskeidingsvermoë, liefde vir God en die gemeente ondersoek kan word wat gelowiges persoonlik, huislik en gemeentelik (kerklik) doen wanneer hulle God ontmoet, na Hom luister en Hom aanbid, godsdiens beoefen en Hom verheerlik. God neem in die ontmoeting die inisiatief en stel die gemeente in staat om Hom en mekaar in Christus deur die werk van die Heilige Gees te ontmoet. (De Klerk 1987:81)

Die werksdefinisie kan dus soos volg verder uitgebrei word: die samekoms van die gemeente kan as ' $n$ dinamiese gebeure beskryf word waarin die deelnemers saamkom om God en mekaar in Gees en waarheid te ontmoet, God te gehoorsaam en met oorgawe te luister en te aanbid. Die luister en aanbidding gaan in huise en in die binnekamer van die gelowige voort, as uitvloeisel van die samekoms van die gemeente as volk van God. Die wegstuurseën stuur gelowiges vanuit die samekoms van die gemeente na die 'liturgie van die lewe'. Die erediens duur voort in die lewe van elke dag, in huisgesinne, werkplekke en ontspannings geleenthede.

Liturgiek is 'n wetenskap wat teorieë vir die praktyk nastreef, dit krities beoordeel en nuwes formuleer waar nodig. Liturgiek beskik oor 'n eie studieveld, vorm eie praktiesteoretiese teorieë en gebruik wetenskaplike metodes. Omdat die Liturgiek hom besig hou met die bestudering van die kommunikatiewe handelings in diens van die evangelie is dit volledig deel van die teologie. Die basis van die liturgiese geloofshandelinge is die handelinge van God met mense in die wêreld, sowel as die handelinge van mense wat hulle geloof kommunikeer met die oog op die ontstaan en opbou van hulle geloof in God (vgl. De Ruijter 2005:20).

In die liturgiese praktyk van die gemeente en gelowiges is die Heilige Gees werksaam as Gees wat van die Vader en die Seun uitgaan. Deur die werking van die Gees kan die stelling gemaak word dat God in, met en deur mense handel, omdat die gemeente die gawe van die Heilige Gees ontvang het. In die liturgiese handelings is die aanwending van die begrip teonome resiprositeit as ruimte waarin die Heilige Gees mense aan die werk sit, belangrik (vgl. Cilliers 1996:68). Teonome resiprositeit beteken nie 'n vereenselwiging tussen God en mense nie, maar is 'n wyse waarop uitdrukking gegee word aan God se genade en die mens se dankbaarheid daaroor, veral waar die gemeente in die erediens saamkom. Die navorser werk met 'n hermeneutiese perspektief waarin die prakties-teologiese interpretasieteorie 'n pneumatologiese uitgangspunt het (Heitink 1993:187-194).

Omdat Liturgiek 'n handelingswetenskap is wat tot die Teologiese Wetenskappe behoort en raakpunte met die menswetenskappe het, gaan dit om die handelings van God deur bemiddelende diens van mense (vgl. Heitink 1993:19). Liturgiek het intradissiplinêre verhoudings met die ander vakke in die wetenskap van die Praktiese Teologie, naamlik Homiletiek, Pastoraal, Gemeentebou, Kategetiek, asook met dieander teologiese wetenskappesoos die Bybelwetenskappe, Dogmatologie, Kerk- en Dogmageskiedenis en Missiologie. Liturgiek staan ook in interdissiplinêre verhoudings met die Sosiale Wetenskappe en is diep betrokke by die huidige kulturele samelewing en konteks (vgl. Osmer 2008:240). In die Liturgiek word, vanuit sy eie aard en betrokkenheid by ander wetenskappe, 'n empiries-analitiese en hermeneutiese benadering gevolg.

\section{Integrering van die verrekening van die metateoretiese aspekte}

In 'n poging om die metateoretiese vertrekpunte te formuleer waarmee 'n reformatoriese wetenskaplike die navorsingsterrein behoort te benader om die wetenskaplike taak te kan uitvoer, word die volgende model visueel voorgestel en verklaar: 


\section{Aanduiding nommer 1}

\section{Die handelende God}

Die handelende God roep deur sy Gees en Woord liturge en erediensdeelnemers op om in sy diens te staan. Die navorser in die Liturgiek sal in die handelingspraksis wat ondersoek word, nagaan in hoe ' $n$ mate dit wat in die erediensdeelnemer se handeling gesien word, die werk van God Drie-enig weerspieël. Erediensdeelnemers sal verder ook hulself onder die leiding van die Gees en die Woord van God moet stel, om so hulle afhanklikheid van God in die drieërlei ontmoeting tussen God, die liturg en die gemeente te erken (De Klerk 1987:82).

\section{Aanduiding nommer 2}

\section{Die navorser se vooronderstellings}

Die navorser wat uit 'n reformatoriese hoek werk, sal sy vooronderstelling uitspel en die werklikheidsgebeure vanuit 'n pneumatologiese benadering ondersoek, naamlik deur die oë van en met die hartsgesindheid van Christus. Hierdie vooronderstellings kan vanuit die resultaat van die interaksie tussen God, sy Woord en die erediensdeelnemers verdiep en verruim word. Die verloop van die navorsingsproses behoort aan kritiese verantwoording oopgestel te word.

\section{Aanduiding nommer 3}

\section{Hermeneutiese lense}

In die gebruik van hermeneutiese lense word die Skrif in nederigheid as primêre gesagsbron gebruik. Daarmee word

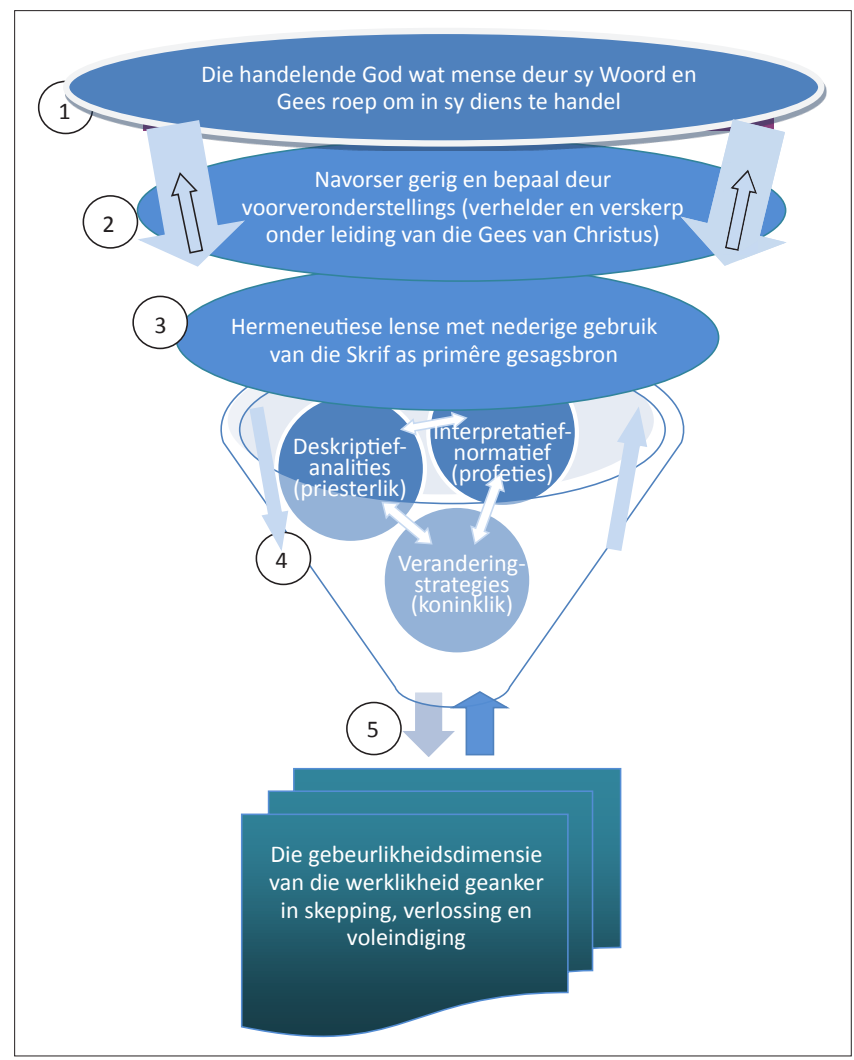

FIGUUR 1: Hermeneutiese model vir die benadering tot die navorsingsterrein hermeneuti. die liturgiese praksis wat waargeneem word, beoordeel in die mate wat dit verteenwoordigend is van die wese en doel van die Liturgiek. Die interpretasie van die Skrif deur die navorser met sy beperkings, moet aan kritiese beoordeling onderwerp word, onder andere deur empiriese gegewens en inligting uit ander menswetenskappe. Dit kan bydra tot die verstaan van verskynsels in die navorsingsveld.

\section{Aanduiding 4}

Deskriptief, interpretatief, normatief, strategies

Dit wat onder leiding van die Gees deur die relevante hermeneutiese lense in die ondersoekveld waargeneem word, kan in verbondenheid met Christus analiserend beskryf word vanuit 'n spiritualiteit van priesterlike bewoënheid, krities-vergelykend, prinsipieel en normatief geïnterpreteer word vanuit 'n spiritualiteit van profetiese onderskeidingsvermoë en gestruktureer word met die oog op strategiese verandering vanuit 'n spiritualiteit van koninklike diensbaarheid (Osmer 2008:33, 81, 135, 183). By die profetiese taak kom twee grondvrae ter sprake, naamlik 'Why is it going on?' en 'What ought to happen?'

\section{Aanduiding 5}

\section{Gebeurlikheidsdimensie van die werklikheid}

In die gerigtheid van die navorser op die kommunikatiewe aspek van die gebeurlikheidsdimensie word op menslike handelings (van die liturg en die erediensdeelnemers) gefokus. Hierdie handelings word in die geloofsverbondenheid of onversoendheid daarvan bepaal met betrekking tot die trinitariese optrede van God wat die lewe van die gelowige deur die kragtige werking van sy Woord met sy skeppende, verlossende en voleindigende handelings omraam.

\section{Voorbeeld hoe die metateoretiese onderbou 'n navorsingsprojek in die Liturgiek stuur: Die wyse waarop God in die doop werksaam is en die effek daarvan op vergifnis en versoening in die Suid-Afrikaanse konteks}

\section{Agtergrond van navorsingsprojek}

Die bedoeling van hierdie voorbeeld is nie om volledige navorsing oor die effek van die doop op vergifnis en versoening te doen nie, maar om aan te dui hoe die metateoretiese vertrekpunte in navorsing in 'n liturgiese aspek toegepas kan word. ${ }^{1}$ Die vraag wat in hierdie voorbeeld gevra word, is of die feit dat God in die doop werksaam is 'n effek op die gedoopte se verantwoordelikheid tot vergifnis en versoening in die Suid-Afrikaanse konteks het. Vanuit die vertrekpunt dat die liturgie van die samekoms 'n drieërlei ontmoeting is waarin God die inisiatief neem om die gemeente te ontmoet en só die gemeente in staat stel om Hom en mekaar te ontmoet, word hierdie vraag benader.

1.Daar word beoog om verdere navorsing oor die effek van die doop op vergewing en versoening in die Suid-Afrikaanse samelewing te doen waarin prinsipiële, empiriese en praktykteoretiese aspekte ondersoek sal word. 
Daar was die afgelope tyd heelwat debatte wat die effek van die doop op die lewe van gelowiges beredeneer. Dit het in die debat oor die sogenaamde tweede doop, die bekeringsdoop of die belydenisdoop ter sprake gekom. Die argument wat ten gunste daarvan aangevoer word, is dat lidmate nie hulle eerste doop wil vervang nie, maar dit simbolies wil aandui en getuig van hulle bekering of herbevestiging van hulle geloof (Beeld 2003:11). Die tendens bestaan in die praktyk dat die doop van kinders nie hoofsaaklik as religieuse fees gevier word nie, maar meer as 'n familiefees en daarom as sosiale geleentheid geniet word. Albei hierdie praktyke spruit moontlik uit ' $n$ dieperliggende gevoel dat die doop nie 'n werklike diepgaande effek op die lewe van 'n gedoopte het nie.

Slegs een effek wat die doop moontlik kon hê, kom in hierdie deel van die artikel ter sprake, naamlik of die doop 'n effek kan en behoort te hê op vergifnis en versoening in die SuidAfrikaanse samelewing. Hierdie aspek word ondersoek, omdat die volgende woorde in een van die wêreldwye kerk se mees algemene belydenisskrifte, die Geloofsbelydenis van Nicea, voorkom: [Ons glo aan ...] 'Een doop tot vergiffenis van sonde'. Die oorspronklike bewoording word nie met 'as vergiffenis van sonde' vertaal nie, maar 'TOT vergiffenis'. Met die 'tot' word aangedui (vgl. Odendal \& Gouws (reds.) 2005:1194): 'lei tot, rigting aandui, ter aanduiding van 'n toestand'. Dit gaan daaroor dat die doop na die vergifnis van sonde heenwys en dat dit 'n sterk toekomsgerigtheid het, maar ook op 'n bevestiging dui.

God het in Christus deur die Gees die doop as teken en seël van die vergifnis van sonde ingestel (Heidelbergse kategismus vraag \& antw. 69 en 70). In die Ons Vader-gebed waarin Christus sy kerk leer bid, is die vyfde bede: 'Vergeef ons ons skulde, soos ons ook ons skuldenaars vergewe'. Op hierdie manier word die vergifnis van die eie sonde verbind aan die roeping om ander te vergewe en so versoening te bedien. Dit het die vraag laat ontstaan of gedooptes, juis omdat hulle gedoop is, hierdie effek van die doop genoegsaam in die praktyk van die Suid-Afrikaanse samelewing laat grondvat.

\section{Die invloed van die reformatoriese werklikheidsbeskouing op die vraag na die effek van die doop op vergifnis en versoening in die Suid-Afrikaanse samelewing}

Hoe lyk die werklikheid waarin die gedooptes in SuidAfrika lewe? In Suid-Afrika is 'n verskeidenheid kulture en sommige mense bestempel die samelewing as multikultureel (Van der Merwe 1996:72). Die oorgang na 'n demokrasie het oënskynlik vreedsaam verloop - hierdie samelewing is in die Mandela-era selfs as 'n reënboognasie beskou. Die Waarheid- en Versoeningskommissie het belangrike werk gedoen om die pyn wat die verdeeldheid en vyandigheid van die verlede veroorsaak het, in die ope te bring. Vergifnis het plaasgevind en daar is aan 'n verskeidenheid oortreders amnestie toegestaan. Na byna twee dekades van demokrasie is dit egter ' $n$ geldige vraag of die metafoor van die reënboog nog gebruik kan word. Die bewoners van Suid-Afrika is steeds veelkleurig, maar of hulle iets van die eenheid van die reënboog vertoon, is te betwyfel. Hofsake waarin rassespanning onderliggend is en klagtes van haatspraak gemaak word, kom meermale voor. Openlike uitsprake selfs van kerkleiers dat hulle lief is vir apartheid en aan 'n soort apartheidsbedeling vashou en hulleself as rassiste bestempel, laat twyfel ontstaan of vergifnis en versoening hoog op die prioriteitslys van Suid-Afrikaners is (vgl. Beeld 2011: 8).

Gedooptes leef in hierdie samelewing. Volgens die jongste statistiek (reeds in 2001 gedoen) het 79.8\% van die bevolking in Suid Afrika aangedui dat hulle Christene is (Statistics South Africa 2004). Van hierdie persentasie is die grootste gedeelte waarskynlik gedoopte Christene. Dit skyn asof selfs hierdie oorweldigende meerderheid nie vergifnis en versoening dinamies kan beïnvloed nie.

Wat sou die probleem wees dat hierdie groot persentasie gedooptes nie vergifnis en versoening in 'n groter mate laat realiseer nie? Daar is waarskynlik meer vertrekpunte moontlik, maar vanuit 'n reformatoriese perspektief is die volgende vertrekpunte die belangrikste:

- God se aktiewe werksaamheid in die doop en die effek daarvan word nie beleef nie.

- Die doop word nie volledig vanuit die trinitariese werksaamheid gesien nie, maar eensydig slegs in geestelike sin, sonder om die doop na die praksis van die samelewing deur te trek.

- Dieverbondsverhoudingwatsterkin die doop funksioneer en waarin die beloftes en eise in wisselwerking is, word onderbeklemtoon.

- Die verband tussen God se vergifnis en versoening en die roeping van die versoende om vergifnis en versoening te bedien, word misgekyk.

Hoe kan die reformatoriese werklikheidsbeskouing, toegepas op die doop, meewerk om verandering te bring? Die eerste en belangrikste perspektief wat hierdie beskouing bring, is dat die Drie-enige God van die Bybel nie sy skepping verlaat het nie. Die Drie-enige God is as Vader, Seun en Heilige Gees steeds getrou herskeppend teenwoordig in die konkrete werklikheid waarin ons daagliks leef (Marais 2007:55).

God stel die doop as sakrament in deur Jesus Christus. Aan Hom gee Hy alle mag in die hemel en op aarde. God neem dus in die handeling van die doop deur alle eeue heen die inisiatief. Die gesag van die Woord bepaal verder hoe die werklikheid waarin die gedoopte lewe, gesien moet word. In Matteus 28:19 is die opdrag van Jesus om te doop 'in die Naam van die Vader, en die Seun en die Heilige Gees'. Die agtergrond waaruit die uitdrukking 'doop in die naam van' verstaan moet word, kom uit die Ou Testament (Versteeg 1983:13). In die besonder moet gedink word aan die seggenskap wat iemand kon uitoefen wanneer sy naam oor iemand anders of oor iets uitgeroep is (vgl. 2 Sam 12:28). Iemand wat in die Naam van die Drie-enige God gedoop is, staan onder die seggenskap van God.

Die gebruik van die voorsetsel sic [in] vestig die aandag daarop dat die Nuwe Testament nie op die doop met of in 
die water fokus nie, maar dat dit altyd oor doop in of tot 'n Persoon. gaan. In die woorde van Ridderbos (1987):

... the words 'baptize "in" (literally 'into') the name of the Father Son and the Holy Spirit' mean that the subject of baptism is brought into fellowship with and under authority of Him in whose name he is baptized. (bl. 554)

Die woord naam (ővo $\mu$ ) word meestal in die Bybel figuurlik gebruik om die persoon of wese self aan te dui (Louw \& Nida 1996[9.19]). In Matteus 28:19 word die dopeling aan die wese van die Drie-enige God en sy mag verbind. Die doop in die Naam van die Vader beteken dat diegene wat die merk van die verbond of van die koninkryk ontvang het, onder sy vaderlike, koninklike sorg staan (Waddell 2009:88). Die doop in die Naam van die Seun, wat Here en Koning is, kan dus as 'n regeringsverandering omskryf word. 'Jesus' baptism did not prepare for the new age; it inaugurated it - when linked with the preaching of Jesus' death and resurrection' (Doriani 2003:39). Dit wat in die doop beteken en verseël word, bevry die dopeling van die slawerny van die sonde en die dood. Dit bring vir die dopeling vergifnis en versoening en stel hom of haar onder 'n nuwe Koning, onder Wie hy of sy vry is om 'n nuwe lewe te lei (Floor 1983:29). Deur die doop in die Naam van die Heilige Gees word die dopeling onder die gesag, die regering van die Heilige Gees gebring. Die Gees is by magte om die hart van die dopeling te verander en te vernuwe, want om die nuwe gesag te erken, vra 'n radikale lewensverandering, 'n nuwe geboorte. Dit is die werk van die Heilige Gees (Krentz 2006:34).

Uit bogenoemde blyk die belang van 'n trinitariese beskouing van die doop, asook die verbondsverhouding wat God in die doop aandui. Die gedoopte word van die feit van vergifnis en versoening verseker. In die Nederlandse Geloofsbelydenis bely die reformatoriese kerke in artikel 34 onder andere: 'Hierdie doop is nie alleen nuttig solank die water op ons is en ons dit ontvang nie, maar ook vir ons hele lewe.' Die doop is ' $n$ bevestiging daarvan dat God in Christus vergewe en verhoudings herstel (versoen.) Dit geld dwarsdeur die lewe van die gedoopte, wat hierdie beloftes gelowig omhels en toeëien.

Hoebehoortgedooptes op hierdie dialogies-kommunikatiewe handeling te reageer? Vanuit die reformatoriese vertrekpunt is menslike handelings in goddelike handelings geanker. God roep tot aksie wat die gedooptes tot gehoorsaamheid aan die verbondseise oproep. Dit sluit in dat die gedooptse vanuit die sekerheid van hulle vergifnis en versoening agente word van vergifnis en versoening in die konteks waarin elkeen lewe.

\section{Die invloed van die reformatoriese hermeneutiese benadering op die vraag na die effek van die doop op vergifnis en versoening in die Suid-Afrikaanse samelewing}

Die reformatoriese hermeneutiese benadering plaas sterk klem op die wisselwerking tussen die Skriftuurlike openbaring oor die doop en sy effek en die konteks van die gedoopte. Die klem sluit die unieke persoon van die gedoopte, sy of haar omstandighede, die leefwêreld en die tydsomstandighede in. Hierdie twee kante kan verstaanshorisonne genoem word, wat in wisselwerking al meer oor mekaar behoort te skuif.

In die hermeneuse gaan dit om die verstaan van hierdie twee horisonne. 'n Pneumatologiese benadering word in albei die prosesse gevolg. Die hermeneutiese sleutel is Jesus Christus wat die verstaan van die doop en die konteks van die gedoopte openbaar. Die fokus is veral op sy bloed van reiniging (vergifnis) en versoening. In hierdie pneumatologiese benadering is die verligting van die Heilige Gees onontbeerlik vir die verstaan van die diepe betekenis van die doop en van die gedoopte as begenadigde sondaar wat op die eise van die verbond kan antwoord. In sodanige benadering is gebed deurgaans deel van die verstaansproses.

Die hermeneutiese metode wat gevolg word, berus op Osmer se onderskeiding van 'n viervoudige taak wat ook vir hierdie verstaansproses geld, naamlik 'n deskriptiefanalitiese taak ('What is going on?'), 'n interpretatiewe taak ('Why is it going on?'), 'n normatiewe taak ('What ought to be going on?') en 'n pragmatiese taak ('How might we respond?') (Osmer 2008:4-11). Hierdie vier take is verbandhoudend en speel voortdurend op mekaar in. In hierdie navorsingsprojek beteken dit dat die Skrifopenbaring oor die doop en die konteks van die gedoopte met 'n priesterlike bewoënheid waargeneem en beskryf sal word ('descriptive task of priestly listening in a spirituality of presence'; Osmer 2008:33). Hierdie twee horisonne behoort ook met die wysheid van die Gees biddend geïnterpreteer te word ('interpretative task in a spirituality of sagely wisdom'; Osmer 2008:81), so behoort die beoordelingsnorme vir die effek van die doop op die gedoopte ten opsigte van vergifnis en versoening, met fyn onderskeiding bepaal te word ('normative task in a spirituality of prophetic discernment'; Osmer 2008:135). In 'n gees van diensbaarheid, moet riglyne vir die verandering in die praksis van die gedoopte se roeping tot vergifnis en versoening in die Suid-Afrikaanse samelewing aangedui word ('pragmatic task in a spirituality of servant leadership'; Osmer 2008:183).

In hierdie hermeneutiese benadering is dit noodsaaklik om 'n verantwoordelike empiriese ondersoek na die gesindheid, houding en praktiese beoefening van die gedoopte te doen ten opsigte van die gedooptes se uitlewing van vergifnis en versoening. Die beste metode is waarskynlik 'n kwalitatiewe ondersoek waarin veral die gesindhede vasgestel kan word. Die wisselwerking met naasliggende menswetenskappe soos Kulturele Antropologie, Sosiologie, Psigologie en waarskynlik Politieke Wetenskap sal die insig oor die konteks van die gedoopte verhelder. In die verstaan van die Skrifopenbaring ten opsigte van die beloftes en eise van die doop, is intradissiplinêre wisselwerking met ander teologiese wetenskappe belangrik. 
Die invloed van die reformatoriese wetenskapsbeskouing op die vraag na die effek van die doop op vergifnis en versoening in die Suid-Afrikaanse samelewing

Omdat daar in die liturgiese handeling van die doop 'n drieërlei ontmoeting plaasvind, die gedoopte in sy doop en in die herinnering daaraan in die elemente van die erediens opgeroep om God oor die doopsgenade te aanbid, Hom oor die eise wat daaraan verbonde is, te gehoorsaam en dit in die liturgie van die lewe, die gebeure van elke dag voort te sit. Om dit te bereik, moet op wetenskaplike vlak teorieë vir die doop in die erediens en die effek van die doop in die samelewing ontwerp word, asook norme vasgestel word om die praksis van vergifnis en versoening in 'n nuwe rigting te kan stuur.

Deur die werking van die Gees, wat van die Vader en die Seun uitgaan, kan God in, met en deur die gedoopte in die samelewing handel om die prosesse van vergifnis en versoening te bevorder.

\section{Slot}

Hierdie navorsingsartikel het eie reformatoriese metateoretiese vertrekpunte ten opsigte van die Liturgiek geformuleer en vasgestel wat die invloed daarvan is in die konteks van veranderings in die denkklimaat, leefwêreld en kultuur waarin die wetenskaplike taak uitgevoer word. 'n Verdere doel was om 'n voorbeeld daar te stel van hoe hierdie metateoretiese beskouing 'n navorsingsprojek kan stuur. Die wyse waarop God in die doop werksaam is en die effek daarvan op vergifnis en versoening in die Suid-Afrikaanse konteks, is die voorbeeld wat gebruik is.

\section{Erkenning \\ Mededingende belange}

Die outeur verklaar dat hy geen finansiële of persoonlike verbintenis het met enige party wat hom nadelig kon beïnvloed in die skryf van hierdie artikel nie.

\section{Literatuurverwysings}

Barnard, M., 2006, Liturgie voorbij de Liturgische Beweging, Meinema, Zoetemeer.

Burger, C.W., 2003, 'Reformed liturgy in the South African context', in L. Vischer (ed.), Christian worship in reformed churches: Past and present, bl. 159-171, Cambridge University Press, Grand Rapids.

Calvijn, J., 1956, Institutie, Deel 1, 3e uitg., vertl. A. Sizoo, Meinema, Delft.

Cilliers, J., 1996, Die uitwissing van God op die kansel, Lux Verbi, Kaapstad.

Compaan, A.L., 2007, 'An alternative moral ontology in a pluralistic, post-apartheid society: Article in honor of DJ Smit', Nederduitse Gereformeerde Teologiese Tydskrif 48(1\&2), 345-355.

Dawn, M.J., 1995, Reaching out without dumbling down: A theology of worship for the turn-of-the-century culture, Eerdmans, Grand Rapids.

De Klerk, B.J., 1987, 'Die Heilige Gees en die verhouding Skriflesing, prediking en gebed in die erediens', ThD proefskrif, $\mathrm{PU}$ vir $\mathrm{CHO}$.

De Klerk, B.J., 2007, 'Basisteoretiese grondslae van die seën in die erediens en voortvloeiende riglyne vir die liturgie', In die Skriflig/In Luce Verbi 41(3), 1-23. http://dx.doi.org/10.4102/ids.v41i3.312
De Klerk, B.J., De Wet, F.W. \& Pieterse, H.J.C., 2012, 'Die noodsaak daarvan om metateoretiese vertrekpunte in prakties-teologiese wetenskapsbeskouing en -beoefening te verreken', In die Skriflig/In Luce Verbi 46(1), 11 bladsye. http:// -beoefening te verreken', In die
dx.doi.org/10.4102/ids.v46i2.59

De Ruijter, K., 2005, Meewerken met God: Ontwerp van een gereformeerde praktische theologie, Kok, Kampen.

De Wet, FW., 2006, 'Die aanwending van Rolf Zerfass se handelingswetenskaplike model in prakties-teologiese teorievorming: 'n Gereformeerde perspektief', In die Skriflig/In Luce Verbi 40(1), 57-87. http://dx.doi.org/10.4102/ids.v40i1.333

De Wet, F.W., 2007, 'Praktykteoretiese merkers vir effektiewe en verantwoordelike integrasie van visuele elemente in die kommunikatiewe struktuur van reformatoriese prediking', Koers 72(4), 603-626. http://dx.doi.org/10.4102/ koers.v72i4.217

De Wet, F.W. \& Pieterse, H.J.C., 2010, 'Die noodsaak van die verrekening van metateoretiese vertrekpunte in prakties-teologiese wetenskapsbeoefening', In die Skriflig/In Luce Verbi 44(3\&4), 525-544. http://dx.doi.org/10.4102/ids. In die Skriflig/ir
v44i3 \&4.160

Dijk, D.J.J., 1998, 'Inclusieve taal in de Liturgie', in P. Oskamp \& N. Schuman, De weg van de liturgie, tradities, achtergronden, praktijk, pp. 395-406, Meinema, Zoetemeer. PMid:9552104

Doriani, D.M., 2003, 'Matthew 28:18-20 and the institution of baptism', in G. Strawbridge, The case for covenantal infant baptism, pp. 30-48, P \& R Publishing, Phillipsburg, New Jersey.

Dreyer, T.F.J., 2005, "Kenotiese" prediking - die katalisator vir liturgiese verdieping in die huidige konteks', Hervormde Teologiese Studies 61(1\&2), 93-108.

“"Ek is 'n rassis," sê ds. Piet', Beeld, 21 April 2011, bl. 8.

Floor, L., 1983, Die heilige doop in die Nuwe Testament, Potchefstroomse Teologiese Publikasies, Potchefstroom.

Heitink, G., 1993, Praktische theologie, geschiedenis, theorie, handelingsvelden, Kok, Kampen. PMid:8333911

Krentz, E., 2006, '“Make disciples": Matthew on evangelism', Currents in Theology and Mission 33(1), 23-41.

'König opper vrae oor tweede doop', Beeld, 11 Februarie, 2003, bl. 11.

Kubicki, J.M., 2006, The presence of Christ in the gathered assembly, Continuum, New York.

Kuyper, A., 1911, Onze eeredienst, Kok, Kampen.

Lathrop, G.W., 1996, 'The shape of the liturgy: A framework for contextualization', in A.S. Stauffer (ed.), Christian worship: Unity in cultural diversity, pp. 67-76, The Lutheran World Federation, Geneva.

Louw, J.P. \& Nida, E.A., 1996, Greek-English lexicon of the New Testament, based on semantic domains, CD-ROM, Libronix digital library system 2001.

Marais, F., 2007, God praat-leef luisterryk: Vir vergaderings, Bybelkor, Wellington.

Mouton, J. \& Marais, H.C., 1989, Basiese begrippe: Metodologie van die Geesteswetenskappe, RGN-Uitgewers, Pretoria.

Odendal, F.F. \& Gouws, R.H. (reds.), 2005, HAT: Verklarende handwoordeboek van die Afrikaanse taal, 5e uitg., Pearson, Pretoria, bl. 1194.

Osmer, R.R., 2008, Practical Theology: An introduction, Eerdmans, Grand Rapids.

Pieterse, H.J.C., 1995, Desmond Tutu's message:A qualitative analysis, Kampen, Weinheim.

Pieterse, H.J.C., 2002, “Prediking in 'n postmoderne lewensgevoel', Praktiese Teologie in Suid-Afrika 17(1), 75-102.

Pieterse, H.J.C., 2011, 'Die noodsaak van die verrekening van metateoretiese aspekte rakende ' $n$ hermeneutiese benadering tot die Praktiese Teologie', In die Skriflig/In Luce Verbi 45(4), 719-737. http://dx.doi.org/10.4102/ids.v45i4.200

Ridderbos, H.N., 1987, Matthew: Bible student's commentary, Zondervan, Grand Rapids.

Smit, D.J., 2003, 'A time for confession? On the WARC project "Reformed Faith and Economic Justice"', Nederduitse Gereformeerde Teologiese Tydskrif 44(3\&4), 478-499.

Statistics South Africa, 2004, Population Cencus 2001, Religion Report, SSA, Pretoria.

Tovey, P., 2004, Inculturation of Christian worship: Exploring the Eucharist, Ashgate, Burlington.

Van der Merwe, W.L., 1996, 'Philosophy and the multi-cultural context of (post) apartheid South Africa', Ethical Perspectives 3, 70-85. http://dx.doi.org/10.2143/ EP.3.2.563038

Van der Walt, B.J., 2010, At home in God's world: A transforming paradigm for being human and for social development, Institute for Contemporary Christianity in Africa, Potchefstroom.

Versteeg, J.P., 1983, 'De doop volgens het Nieuwe Testament', in W. Van't Spijker et al. (red.), Rondom de doopvont: Leer en gebruik van de heilige doop in het Nieuwe Testament en in de geschiedenis van de westerse kerk, De Groot Goudriaan, Kampen.

Vos, C.J.A. \& Pieterse, H.J.C., 1997, Hoe lieflik is U woning: Studies in Praktiese Teologie, RGN-Uitgewery, Pretoria.

Waddell, P., 2009, 'Ordained by Christ in his church: Jesus and baptism', Theology 112(866), 83-91.

Wepener, C., 2007, 'Participation and power: Opportunities for method and theory in liturgical research from a changing (Dutch Reformed) South African liturgical landscape', Nederduitse Gereformeerde Teologiese Tydskrif 48(3\&4):730-742. 